\title{
Can Businesses in India ever resolve Disputes Speedily and Effectively?
}

\author{
Anurag K. Agarwal
}

W.P. No. 2006-06-05

June 2006

The main objective of the working paper series of the IIMA is to help faculty members, Research Staff and Doctoral Students to speedily share their research findings with professional colleagues, and to test out their research findings at the pre-publication stage

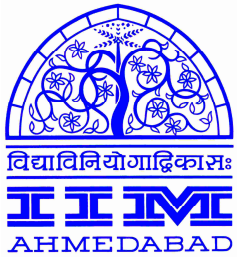

INDIAN INSTITUTE OF MANAGEMENT

AHMEDABAD-380 015

INDIA 


\title{
Can Businesses in India ever resolve Disputes Speedily and Effectively?
}

\author{
Anurag K. Agarwal*
}

\begin{abstract}
Business disputes are like cancer which should be stopped from spreading as soon as possible. Litigation is the least favoured method of resolution for a variety of reasons - delay being the foremost. Alternative Dispute Resolution (ADR) methods like negotiation, mediation, conciliation, arbitration are currently in vogue. Unfortunately, there is a strong feeling in India that extralegal methods provide timely solutions for business disputes. This does not augur well for the business environment. The paper examines the business dispute resolution scenario in India and provides suggestions for making it more speedy and effective in a legal manner.
\end{abstract}

Keywords: ADR, Business disputes, Courts, India

\footnotetext{
${ }^{*}$ LL.M. (Harvard), LL.D. (Lucknow); Faculty - Business Policy Area, Indian Institute of Management
} Ahmedabad; akagarwal@iimahd.ernet.in 


\section{Can Businesses in India ever resolve Disputes Speedily and Effectively?}

\section{Introduction}

The Indian judicial system is marred by delays. Businesses suffer because disputes are not resolved in a reasonable time. Even with the use of methods of alternative dispute resolution a fair number of high value disputes end up in a court. Thus, courts hardly have any time for taking up disputes of lower value. Also, in a country of continental dimensions, every disputant cannot afford to travel and contest in a court of law.

With a population of more than one billion, a huge middle-class with substantial purchasing power, fast growing economy, and a market of continental size, India, today, can not be ignored. Along with these factors, democracy, rule of law and independence of the judiciary make India an attractive place to do business. The judicial system based on the English model, provides the much needed confidence to the foreign investors and business community. However, the delay associated with the judicial system, particularly at the level of lower judiciary, has prompted many commentators to say that the judicial system has collapsed in India. The clichéd saying, "justice delayed is justice denied" has been quoted so often that it has lost its meaning. This, however, is not a recent phenomenon. In 1952 Mr. Motilal C. Setalvad, the first Attorney General of Free India, wrote, "A burning problem which the citizens, lawyers and judges face alike is that of the congestion of Courts of law and the consequent inordinate delays in the administration of justice..." (Setalvad 1952)

Three and a half decades later, on November 26, 1985, in his Law Day (the day Indian Constitution was adopted by the Constituent Assembly in 1949) speech, the then Chief Justice of India painted a very dismal picture. He said, "I am pained to observe that the judicial system in the country is almost on the verge of collapse. These are strong words I am using but it is with considerable anguish that I say so. Our judicial system is creeking under the weight of arrears." It was quoted by Mr. Ashok Desai, Attorney General in 1996, when the situation was no different from 1985. (Desai, 1985)

Things have not changed much since then. Delay has become almost synonymous with judiciary in India. The courts are seen to be so preoccupied with procedural matters that trials only commence after long delays and, once begun, are conducted at a snail's pace. Monetary claims and commercial litigation that does not involve interim relief can take many years to decide, and judges are reportedly reluctant to award costs or realistic interest.

Courts in India, particularly the higher courts, are usually perceived as impartial. Trial courts, however, are under great stress. The judicial officers (Judges and Magistrates) at this lowest judicial level are government servants of the province in which the court is situated. Hence, these judges do not have absolute (as compared to High Court and Supreme Court judges) financial and otherwise independence. They work often under the Damocles sword of the executive of the state, which has the power of transfer and controlling other service matters. Therefore, corruption, mal-practices and abuse of power are not uncommon. Decisions may be swayed by political, official or other pressures or 
because of lure of lucre or threats to cause damage to judge's property or person. Adequate protection is not provided to the officers of the state judiciary. Moreover, the workload (number of cases per judge) is extremely high. This often results in poor quality of judgments, low morale of the judicial officers and absence of real system of justice at the District level.

It is said that "arbitration is better than litigation, conciliation better than arbitration, and prevention of legal disputes better than conciliation." The truth of the saying in practical field cannot be ignored. The objects of arbitration are speediness, cheapness, convenience, and simplicity of procedure, secrecy and the encouragement of healthy and friendly relations between the disputants. It has been found from experience that when the disputes between the parties relate only to questions of fact, e.g., whether the goods are of contracted quality or specification or as per sample, arbitration is by far the most advantageous machinery for settlement of such disputes. Under the rules of various trade associations "quality arbitration" is arranged which provides for expeditious, cheap disposal of such matters which seldom gives rise to subsequent litigation in court. But the cases where the disputes concern only question of law (the facts being undisputed), e.g., construction of a document or any other pure question of law, it is often cheaper and expeditious to have such disputes decided by a court of law. Sometimes it appears that the objects of arbitration are abused. Very often it is found to be more expensive and protracted than litigation. This is not due to the inherent defect of the arbitration machinery, but due to the technique of operation of the machinery by human agency. Honest men dread arbitration more than they dread law suits. Bhandari (2005) observes that mediation and conciliation techniques are likely to have a good result in matrimonial matters and other family disputes, such as partition, partnership disputes, etc. And, mediation has been practiced in the society from time immemorial. However, as there is no binding effect of these techniques, these are not the best techniques for business disputes.

Commercial arbitration has been hailed as the most efficient form of dispute settlement available to participants in international trade. Many commercial entities view the arbitral tribunal as a neutral and cost-effective alternative to what they perceived as biased, expensive and time-consuming national courts. As a result of the increasing respect accorded to arbitration, the standard form arbitration clause included in international contracts is now receiving much greater consideration than it did in the past. Because arbitration is frequently the dispute settlement method of choice for enterprises dealing with their counterparts in other countries, importance of international commercial arbitration has increased. Indeed, it has become the dominant method of settling international trade disputes (Varady, Barcelo III and von Mehren, 1999).

Like arbitration, conciliation and mediation offer the parties great procedural flexibility. The parties pick conciliators or arbitrators of their choice and design procedures that best fit their cases. A mediator seeks to reduce the distance between the parties' positions and make the parties understand each other's point of view, in order that they may achieve a compromise solution. A conciliator performs a different function. After consulting all sides and evaluating the evidence, the conciliator draws up the terms of a solution that is hopefully acceptable to all parties involved in the dispute. Conciliation and mediation differ in one important respect from arbitration: they do no result in a binding or enforceable award. A mediator cannot compel the parties to reach a settlement, and a conciliator has no power to impose a compromise solution on the parties. For this reason, ADR is sometimes combined with an adjudicatory process as a fall-back solution. For 
example, a contract may provide for a specific time limit to start some form of mediation or negotiation after which arbitration becomes the only method available.

Arbitration is a reference of some matter or matters in difference between parties to the decision of one or more persons either with or without an umpire. An arbitration room is a forum of confession. The difference between an arbitration room and a court of justice is that the former is a tribunal chosen by the parties themselves, but the latter is a forum over which the parties have no choice. A matter comes as adversely before an arbitrator as before any other tribunal or a court of justice. In short, an arbitration agreement relates to some person other than a court of competent jurisdiction. It is necessary to note that there is no clear guideline as to whether arbitration is better than litigation or vice versa. Preference of one to the other depends on weighing advantages of the both.

Delay in getting a dispute resolved is not good for the economy of any country. As the courts are clogged with regular litigation matter, it is a good idea for business related disputes to be resolved through arbitration (Agarwal, 1999) or any other alternative dispute resolution method, preferably one having the binding effect.

In USA various forms of Alternative Disputes Resolution (ADR) have been introduced owing to high costs of litigation and commercial arbitration. American companies doing business in Europe and elsewhere resort to ADR. It is a probationary period for ADR. Some forms of ADR are intended to lead a binding result. ADR is sometimes known as 'mini-trial' which is akin to mediation. In a mini trial the relentless pressure is missing. There is temptation for each party to go on repeating its original case. The most basic feature of this kind of resolution is that it is a settlement conference: parties are required to send their attorneys to a meeting generally with the Judge or a magistrate after completion of discovery of each side's claim and/or position. In the conference a Judge seizes the opportunity to focus the attention of the parties on the issues they are trying to avoid for settlement of the disputed areas, some Judges take many assertive steps to bring about a negotiated settlement and some take a reasonal attitude for settlement of the disputes.

Nariman (1999) says that if the arbitrator is old-fashioned, he may only suggest that the dispute could be more appropriately settled with the intervention of a third party, and adjourn the arbitral proceedings for a brief period to enable parties to approach some third party as mediator: obviously, he cannot impose on the parties a 'solution' of mediation. And, here lies the importance of arbitration. The order of the arbitrator called the award is binding on the parties.

\section{Institutional and Ad hoc arbitration}

International Commercial Arbitration can be conducted in two ways: (1) as institutional arbitration, or (2) ad hoc arbitration. Institutional arbitration is done under the aegis of an arbitral centre, usually according to the institution's own rules of arbitration. It is also referred to as 'administered' or 'supervised' arbitration. Ad hoc arbitration differs from institutional arbitration in that it does not rely on the supervision or formal administration of an arbitration centre. The parties are 'on their own'. They are not bound by time limits set by arbitral institutions, and their proceedings are not monitored by any central body. The parties can leave the issuance of arbitration procedures to their arbitrators or develop their own rules and design their own arbitral management either in the initial contract or after a dispute has arisen. Alternatively, the parties may simply adopt or adapt the rules of 
one of the major arbitration centres but, again, without entrusting the administration of the arbitration to such centres. Ad hoc arbitration to resolve international commercial disputes is similar to ADR in that neither the mediator nor the conciliator is monitored by any central institution. Like the mediator and conciliator, the arbitrator depends entirely on the good will of the parties for a smooth process of dispute resolution (Russell, 2003).

Many of today's arbitration practices evoke medieval Europe's private courts and the Law Merchant, a body of private commercial rules and principles that were distinct from the ordinary law of the land. The merchant courts sat in fairs, markets, seaport towns, and most other large centres of commercial activity. Merchant courts chose as judges merchants who possessed intimate knowledge of particular commercial practices and techniques. Merchant courts relied on sanctions such as ostracism and boycott of all future trade to ensure that traders would be held to the resolution dictated by the arbiters.

It is apparent that good will, the prerequisite for successful use of ADR or ad hoc arbitration, can no longer be taken for granted after a contractual relationship has ended. In such a situation, ADR and ad hoc arbitration are doomed to failure. The only hope is from the institutional arbitration. Majority of disputes submitted to institutional arbitration arise shortly before or after a commercial relationship has ended. In cases when one party terminates the contract, the other party becomes highly non-cooperative. It may prefer to defect from 'surviving obligations' and try to evade the contractual obligation to arbitrate the dispute, arguing that the matter falls under its national jurisdiction and can only be decided in a national court according to national law and procedural rules. Later, the party may seek to derail the arbitral proceedings by disagreeing on the choice of arbitrator(s), procedural rules, place and language of arbitration, and applicable law. It could also try to delay the proceedings by failing to appear on dates selected for hearings or by raising questions over procedural matters. If none of these dilatory tactics succeeds, the party still has the option of challenging the arbitral award before a national court, on the basis that the arbitral tribunal exceeded its jurisdiction or that there was a substantial miscarriage of justice in the course of the proceedings. Finally, the party may simply choose not to honour the arbitral award.

With a number of advantages, international commercial arbitration may seem to be the panacea for all international commercial disputes. This is not the case. Many times litigation is preferred to international commercial arbitration:

a) Multi-Party disputes - Litigation is preferred in case of multi-party disputes. In such cases, arbitration may be unwieldy as transactions involve too many participants. Litigation techniques for dealing with multiple parties are more advanced.

b) Litigation to avoid arbitration - In a dispute involving very high stakes, there may not only be specified arbitration, but also litigation resulting from attempts to avoid the arbitration.

c) Speedy relief unlikely - In arbitration, a panel must be selected before anything substantive can happen. Appointment of arbitrators itself consumes a lot of time in bitter disputes. Sometime, a court has to be approached for appointment of arbitrator(s). Therefore, speedy relief is unlikely. Also, in cases of urgent provisional intervention by the courts, the courts are reluctant to go beyond the barest maintenance of status quo and want to avoid intruding on matters that are within the jurisdiction of arbitral tribunal. 
d) Intricate questions of law - Arbitration is not the method of choice when intricate questions of law are involved. Also, the interpretation of statutes or contract may pose problems of strictly legal nature to the arbitral tribunal.

In such situations, it is easy to see why ad hoc arbitration and ADR are ill-suited. Extensive monitoring and strong institutional safeguards are necessary to deprive potential bad faith and other forms of defection of their effects in such cases. Institutional arbitrations are best suited to handle such difficult cases. Efforts had been done to harmonise the arbitration law and make it more efficacious. One such effort has been the New York Convention

\section{The New York Convention and the UNCITRAL Model Law}

In 1958, forty-five countries, including India and the United States, participated in the U. N. conference that culminated in the New York Convention. The Convention encourages the recognition and enforcement of international arbitration agreements and awards. India was a signatory of the Convention and the Indian Parliament ratified it on July 13, 1960. The U.S., however, signed it only in September 1970. The U.S. delegation to the conference had recommended that the United States should not enter into the Convention. The delegation was concerned that the U.S. would not benefit if the Convention were implemented in a manner that avoided conflict with state anti-arbitration laws. For the United States to benefit, the Convention would need to override state anti-arbitration laws, which would require changes in state and possibly federal court procedural rules. At that time, courts in the United States viewed arbitration agreements with the jaundiced eye to oust their jurisdiction. Within a decade, however, domestic attitude toward the Convention had changed. American businesses were having difficulty enforcing arbitral awards against parties situated abroad. In October 1968, the Senate gave its advice and consent to the Convention and on September 30, 1970, the U.S. signed the Convention, however, with the following 'declarations and reservations':

- The United States of America will apply the Convention, on the basis of reciprocity, to the recognition and enforcement of only those awards made in the territory of another Contracting State.

- The United States of America will apply the Convention only to differences arising out of legal relationships, whether contractual or not, which are considered as commercial under the national law of the United States.

One aspect that should be noted is that of the 137 states that are signatories to the Convention, only 46 adopted the "commercial reservation" with respect to the Convention. Interestingly, many common law countries like India, the USA, Canada, etc. have also adopted this reservation, despite the fact that there is no general distinction between "commercial" and "non-commercial" contracts as understood in civil law countries. One possible reason why these countries kept the "commercial reservation" could be because they were concerned about issues relating to sovereign immunity.

Thus, the effect of the reservation was that each country could restrict the application of the Convention to only those matters which were considered to be commercial under the law of that particular country. Since, different countries defined and interpreted the word "commercial" differently, it gave rise to many problems. Hence, during the drafting of the UNCITRAL Model Law, when there was a renewed exercise to bring about unification 
and harmonization of ICA law across the world, there was an attempt to provide a definition of the word "commercial." However, this did not prove to be an easy task. Countries like Mexico specifically wanted foreign direct investments and financial transactions entered by the government to be excluded (as they are considered to be part of public debt). On the other hand, countries like Germany and the United States specifically wanted a clause to expressly state that the nature of the transaction i.e. whether it was commercial or not would not depend on the nature and character of the parties to the transaction. Thus, for example the fact that a person who is not a merchant had entered into an otherwise commercial transaction would have no effect on the commerciality of the transaction.

Since its inception in 1966, the United Nations Commission on International Trade Law (UNCITRAL) has worked to improve the effectiveness of international commercial arbitration. In particular, UNCITRAL has sought to improve the enforceability of arbitral awards and to remove obstacles to their recognition and enforcement. In 1976, UNCITRAL adopted a set of 'rules' to guide contracting parties resorting to arbitration and to streamline the arbitration process. Today, the UNCITRAL rules have been widely accepted and are considered to have 'world-wide' significance. In 1985, UNCITRAL produced the final draft of a 'Model Law' on International Commercial Arbitration (Model Law). The Model Law process involved the creation of uniform rules to eliminate local peculiarities which make international consistency impossible in certain areas of law. The promulgation of the Model Law was consistent with UNCITRAL's general mandate 'to promote the progressive harmonisation and unification of the law of international trade.' The Model Law is a comprehensive work governing the arbitration agreement, the composition and jurisdiction of the arbitral tribunal, the conduct of arbitral proceedings, and making of and recourse against the award. On December 11, 1985, the General Assembly of the United Nations recommended that all Member States adopt the Model Law as their domestic law regulating the conduct of international commercial arbitration.

Palkhivala (1994) expressed his views about the international commercial arbitration in the following words, "When the International Chamber of Commerce at Paris started offering the services of its Court of Arbitration, businessmen in different countries found it convenient to avail themselves of that facility. In course of time that 'convenience' became a 'preference' and the preference has now ripened into a necessity." He further stated, "If I were appointed the dictator of a country, in the short period between my appointment and my assassination I would definitely impose a law making international arbitration compulsory in all international commercial contracts."

Rapid growth of trade and commerce has made it possible to generate disputes in international commercial transaction as a result of which a large number of disputes are being adjudicated by different International Arbitration Tribunal in developed, developing and underdeveloped countries all over the world,. Thus the machinery providing for substantive law of arbitration of the contract of the parties, the venue of arbitration and procedural law relating to arbitration has been set up.

There is no accepted definition of the term 'commercial' but it has become a part of language. It serves, for instance, to distinguish international commercial arbitrations from international arbitrations between the States concerned with boundary disputes or other political issues. It also serves to distinguish them from domestic arbitrations dealing with the property, employment and family law disputes. It may be said that the term 
commercial has now acquired a significant and definitive meaning so as to set up a commercial court which deals only with disputes arising out of trading and other commercial relationships.

The Model Law does not define the word "commercial" but states:

"The term 'commercial' should be given a wide interpretation so as to cover matters arising from all relationships of a commercial nature, whether contractual or not. Relationships of a commercial nature include, but are not limited to, the following transactions: any trade transaction for the supply or exchange of goods or services; distribution agreement, commercial representation or agency; factoring; leasing; construction of works; consulting; engineering; licensing; investment; financing; banking; insurance; exploitation agreement or concession; joint venture and other forms of industrial or business cooperation; carriage of goods or passengers by air, sea, rail or road."

It can reasonably be inferred that the Model Law progresses from the Convention, as the Convention had no guidance on this issue whatsoever and left it completely at each nation's discretion. However, it should be noted that the interpretation of the word "commercial" still remains important. This is because countries like India have retained the "commercial reservation" even after enacting a new law on the lines of the Model Law. The Convention might still govern a number of cases despite the fact that the countries have enacted the Model Law. Moreover, as compared to the Convention, only 48 states have enacted legislations based on the Model Law.

It is useful to apply and follow the wide definition of the term 'commercial' so as to include all aspects of international business, or deciding whether a particular agreement is commercial, reference must be made to the national law of the parties concerned.

\section{Technology provides the solution}

History tells us that technology has provided the answer on most of the occasions of difficulty. Internet has emerged as one of the most significant and revolutionary inventions of our time. It has a large number of applications. Dispute resolution is also one of them. With increase in globalisation of business, the business disputes are also getting more and more global in character. The traditional methods of resolving such business disputes have become very expensive and consume a lot of time. Litigation was never the method of choice for resolution of international business disputes. ADR methods were favoured. With the use of internet, a new method has evolved - Online Dispute Resolution. According to the American Bar Association Task Force on ECommerce and ADR, "Online Dispute Resolution has only one overarching feature - it takes place online." Further, "ODR encompasses many forms of ADR and court proceedings that incorporate the use of the Internet, Web sites, e-mail communications, streaming media and other information technology as part of the dispute resolution process."

There are three current approaches to ODR: cyberspace, non-adjudicative ADR, and arbitration. The first centres on the Internet and information technology. The principle underlying the cyberspace approach is to find better, faster and cheaper ways to resolve disputes with the aid of technology. The non-adjudicative ADR approach to ODR focuses mainly on negotiation and mediation, and how to improve both communications and 
relationships between parties. The arbitration approach emphasises rights and applications of law to resolve the dispute with an arbitrator's decision. The impetus behind this approach is the success of traditional arbitration. If it works so well offline, then it should be adapted online, the reasoning goes (Kaufmann-Kohler \& Schultz, 2004).

The fact that commercial law and commercial activity in India were confined to the presidency town, led to a kind of fossilization in the legal system. Judges outside the commercial towns were not very sensitive towards the needs of business. The slightest flaw in the arbitration procedure, the slightest departure from the norms of fairness and the slightest deviation from statutory provisions would be regarded as sufficient to set aside an award. Judges with the red pencil in their hands and, rightly or wrongly, believing themselves to be bound to apply the law in all its strictness, would remit or quash an arbitration award, though no substantial injustice was done by the award. This mindset needs to be changed with time and use of technology will be beneficial only when such change is brought sooner than later. Nariman (2004) has hit the nail on the head by observing that it is high time to foster the growth of an international arbitration culture amongst lawyers, judges and National Courts.

ODR as a method of dispute resolution can only be successful when courts are kept out of the loop. This is somehow not possible in India as can be understood with our experience of arbitration. Courts have been very liberal in granting interim injunctions to the parties to arbitration at the drop of a hat. Rautrey (2005) observes that Indian courts have been too eager to interfere in the arbitration proceedings. Claims worth millions of rupees have been waiting for a green signal from the courts as the arbitration proceedings have been stayed for matters as trivial as fixing of a date or venue of arbitration. ODR should not go the same way.

\section{Conclusion}

The courts in India have realised that it is not possible for the existing judicial system to cater to the dispute resolution demands of the citizens of India. Particularly with reference to business disputes the courts have emphasised to use ADR methods and also to go to Lok Adalats, which are friendly courts officiated by sitting or retired judges and decisions are made on the basis of settlement. The decision of a Lok Adalat is final and binding on the parties and cannot be challenged in any court. The Supreme Court has also upheld the changes made in the procedural law to make decision making faster (Supreme Court of India, 2005). The courts are also encouraging the use of technology, like video conferencing, for speedier resolution of disputes. Thus, the judiciary is in favour of the use of latest technology. The only caveat may be that it should not widen the inequality in society.

One of the greatest advantages of ADR is that the parties are free to choose the law, procedure, venue, arbitrators or conciliators and almost everything related to the resolution of the dispute. The parties are also free to decide whether they would like to go for ADR or not. No one can compel them to resort to ADR. Although the right to arbitration is not as yet recognised as a fundamental human right, it is time that arbitral freedom - freedom of parties to refer commercial disputes to arbitration - is proclaimed as a universally acceptable principle of dispute resolution. However, more party autonomy means lesser control of courts. Arbitration or any other system of ADR will work as good as the people managing it wish to make. There is a dearth of trained personnel to man different roles of ADR - lawyers, judges, administrative staff. Even 
there is a lack of culture of getting disputes resolved through ADR. However, it is high time that businesses in India start using the methods of alternative dispute resolution including online dispute resolution for resolution of the business disputes. It is the trend globally and we need not follow the same old method of litigation which takes years and at times decades to get even simple matters resolved. Time is money and specially for the business community. They can ill-afford to waste even a single second on avoidable litigation. Without even an iota of doubt, the businesses in India should go whole hog for ADR. It shall put them on par with global businesses in matters of dispute resolution.

\section{References}

1. Agarwal, Anurag K., 1999 "Justice Delayed is Justice Denied - Speedy Justice through Arbitration” All India Reporter 1999 Journal 177

2. Bhandari, Dalveer, 2005 (Hon'ble Chief Justice, Bombay High Court), "Mediation and Alternate Litigation" Indian Council of Arbitration Journal Vol. XXXIX/No. 4 January - March, 2005, Pp. $1-2$.

3. Desai Ashok H., 1997 "Law Day Speech", 1997 Supreme Court Cases (Journal Section), Volume 2, pp. 10-12

4. Kaufmann-Kohler G. \& Schultz, T., 2004 “Online Dispute Resolution: Challenges for Contemporary Justice" (The Hague, The Netherlands: Kluwer Law International, 2004)

5. Nariman, Fali S. 1999 "Mediation and the Arbitrators", Arbitration in the Next Decade - Special Supplement, 1999, ICC International Court of Arbitration Bulletin, Pp. $43-47$.

6. Nariman, Fali S. 2004 "Recent Developments in the World of International Commercial Arbitration" Indian Council of Arbitration Journal Vol. XXXIX/No. 3 October - December, 2004, Pp. $4-8$.

7. Palkhivala, Nani A., 1994 "We, The Nation: The Lost Decades", U B S Publishers' Distributors Ltd., New Delhi, 1994

8. Rautray, D., 2005, (Kachwaha \& Partners, India) "Anti-Arbitration Injunction in India", April 12, 2005, www.mondaq.com

9. Russell on Arbitration by David St. John Sutton and Judith Gill, Sweet \& Maxwell Limited, London, 2003, Twenty-Second Edition, para 5-125, p. 195

10. Setalvad, Motilal C., 1952 "Problems before Legal Profession", All India Reporter (Journal Section), Volume 39, AIR 1952 Journal 2

11. Supreme Court of India, 2005, "Salem Advocate Bar Association, Tamil Nadu v. Union of India", 2005 Supreme Court Cases, Volume 6, p. 344

12. Varady, Tibor, Barcelo III, John J. and von Mehren Arthur T., 1999 "International Commercial Arbitration: A Transnational Perspective", West Group - American Casebook Series, St. Paul, Minn., U.S., Preface 